\title{
Metode Markov Chain untuk Menghitung Premi Asuransi pada Pasien Demam Berdarah Dengue
}

\author{
${ }^{1}$ Irwan, ${ }^{2}$ Didiharyono, ${ }^{3}$ Maulidina \\ 1,3 Program Studi Matematika, Fakultas Sains dan Teknologi, UIN Alauddin Makassar \\ ${ }^{2}$ Fakultas Ekonomi, Universitas Andi Djemma \\ 1Jl. H.M.Yasin Limpo No.36 Romangpolong, Gowa, Sulawesi Selatan, 92118 \\ Email:irwan.msi@uin-alauddin.ac.id
}

Article History:

Received: 11-08-2019; Received in Revised: 19-10-2019; Accepted: 30-10-2019

\begin{abstract}
This paper discusses the Markov Chain method in calculating insurance premiums for patients with dengue hemorrhagic fever (DHF) at Labuang Baji Hospital. The Markov Chain Model is a method that studies the characteristics of a variable in the present that depends on its properties in the past in an attempt to estimate the properties of these variables in the future. This paper aims to determine the transition probability model for each circumstance using the Markov multistate model and to determine insurance premiums using the Markov Method. Based on the results of research and discussion, obtained a probability transition model matrix with the order $5 x$. Next calculate the transition rate matrix, calculate the transition opportunity, calculate the density function, and calculate the premium of each event. With a large one-year term life insurance premium paid to patients with Dengue Hemorrhagic Fever (DHF) at each transition opportunity adjusted to the state of each gradient I, II, and III, with the maximum value of the premium paid that is at the state of the gradient I that moves to die with the value $\bar{A}_{x: \overline{1} \mid 04}=R p .1 .372 .500$.
\end{abstract}

Keywords: Markov Chain; Transition Probability Matrix; Transition Rate Matrix; Transition Opportunities; Insurance premium.

\begin{abstract}
Abstrak
Tulisan ini membahas tentang metode Markov Chain dalam menghitung premi asuransi pada penderita penyakit demam berdarah dengue (DBD) di Rumah Sakit Labuang Baji. Model Markov Chain merupakan salah satu metode yang mengkaji sifat-sifat suatu variabel saat sekarang bergantung pada sifat-sifat variabel di masa terdahulu untuk mengestimasi sifatsifat variabel tersebut untuk keperluan di masa mendatang. Tulisan ini bertujuan untuk mengetahui model probabilitas transisi dari setiap keadaan dengan menggunakan model multistatus Markov dan untuk menentukan premi Asuransi menggunakan Metode Markov. Berdasarkan hasil penelitian diperoleh model matriks probabilitas transisi berordo 5 x 5 . Selanjutnya menghitung matriks laju transisi, menghitung peluang transisi, menghitung fungsi densitas, dan menghitung premi dari setiap kejadian. Dengan Besar premi asuransi jiwa berjangka satu tahun yang dibayarkan pada pasien Demam Berdarah Dengue (DBD) pada setiap peluang transisi disesuaikan dengan keadaan masing-masing gradiasi I, II, dan III, dengan nilai maksimal premi yang di bayarkan yaitu pada keadaan gradiasi I yang berpindah ke meninggal dengan nilai $\bar{A}_{x: \overline{1} \mid 04}=R p .1 .372 .500$.
\end{abstract}

Kata Kunci: Makrov Chain; Matriks Probabilitas Transisi; Matriks Laju Transisi; Peluang Transisi; Premi Asuransi. 


\section{Pendahuluan}

Asuransi sangat diperlukan sebagai pengalihan dari berbagai resiko yang terduga maupun tidak terduga yang terjadi pada manusia. Asuransi merupakan suatu keinginan secara suka rela dalam menetapkan kerugian yang sedikit sebagai pengganti kerugian besar yang belum pasti kejadiannya di masa mendatang. Fungsi utama asuransi yaitu sebagai mekanisme mengalihkan resiko (risk transfer mecanisme) yaitu mengalihkan resiko dari suatu pihak tertanggung kepada pihak penanggung1.

Asuransi merupakan bentuk kerja sama untuk menghindari atau minimal mengurangi resiko. Risiko-risiko tersebut adalah risiko sakit, risiko kematian, risiko hari tua, dan risiko kecelakaan. Dari risiko tersebut dapat dijadikan sebagai model dengan banyak kasus yang disebut kasus multistate ${ }^{2}$. Untuk mengetahui peluang perpindahan dari state satu ke state lainnya digunakan peluang transisi yaitu dengan dengan mengetahui state awal pada waktu sebelumnya maka akan diketahui state selanjutnya pada waktu berikutnya ${ }^{3}$.

Pada kasus multistate, peluang transisi menggunakan konsep dasar rantai markov. Rantai markov adalah suatu kasus spesifik dari proses markov yang bertujuan untuk mengkaji perilaku sistem berdasarkan waktu tertentu. Sedangkan, proses markov merupakan suatu sistem dengan model stokastik yang memiliki sifat bahwa terjadinya suatu keadaan atau kondisi yang terjadi bergantung pada kondisi atau keadaan sebelumnya ${ }^{4}$.

Penyakit DBD merupakan salah satu penyakit menular yang menyebabkan kematian dalam waktu singkat dan sering menimbulkan wabah pada suatu wilayah. Di Indonesia mempunyai resiko untuk terjangkit penyakit DBD karena virus penyebabnya bersumber dari nyamuk, tersebar luas baik di rumah maupun tempat-tempat umum, kecuali yang ketinggian lebih dari 1.000 meter di atas permukaan laut ${ }^{5}$. Oleh karenanya, pasien penderita penyakit Demam Berdarah Dengue diperlukan untuk menghitung premi asuransi sebagai pengalihan dari berbagai resiko yang mungkin terjadi

${ }^{1}$ Zuhairo Faihatuz, Diklat Kuliah Matematika Asuransi (Makassar: FST UIN Alauddin, 2012).

2 Rianti Siswi Utami and Adhitya Ronnie Effendie, "Model Hidden Markov Multistatus Untuk Menghitung Premi Asuransi Kesehatan," 2014, http://etd.repository.ugm.ac.id/home/detail_pencarian/69145.

3 Aminah Sitti and dkk, "Premi Untuk Asuransi Jiwa Berjangka Pada Kasus Multistate" (Skripsi, Riau, Universitas Riau, 2015).

4 Fabio Baione and Susanna Levantesi, "A Health Insurance Pricing Model Based on Prevalence Rates: Application to Critical Illness Insurance," Insurance: Mathematics and Economics 58, no. C (2014): 174-84.

5 Anna Islamiyati, "Estimator Penalized Spline Pada Model Regresi Nonparametrik Multirespon Multiprediktor Untuk Data Longitudinal" (postdoctoral, Universitas Airlangga, 2019), http://lib.unair.ac.id. 
dan juga sebagai pengendalian (control) ${ }^{6}$ dalam menghindari kemungkinan terjadinya resiko.

Banyak kajian yang dilakukan oleh peneliti berkaitan dengan perhitungan nilai premi asuransi. Ada yang menentukan nilai premi tunggal aktuaria (actuarial present value) pada kasus multi-state untuk data CCRC dengan hasil yaitu Menentukan Nilai Premi Tunggal, APV, melalui pendekatan multi-state stokastik memberikan beberapa hal diantaranya dengan pendekatan multi-state yang melibatkan peluang transisi antarstate dan membentuk distribusi peluang, penghitungan APV menjadi lebih praktis dan menyeluruh, walaupun sebatas kajian teori, nilai-nilai APV partial dapat dihitung sehingga membuka peluang untuk dikaji lebih dalam, khususnya berkaitan dengan terapannya ${ }^{7}$.

Premi untuk asuransi jiwa berjangka pada kasus multistate dengan hasil yaitu peluang transisi dari state-i ke state-j untuk asuransi jiwa berjangka pada kasus tiga state dapat dicari dengan terlebih dahulu menentukan laju transisinya dan menyusun ke dalam bentuk matriks ${ }^{8}$. Premi tunggal pada asuransi jiwa berjangka dengan kasus multistate dipengaruhi oleh peluang transisi yang merupakan pengganti dari peluang bertahan pada premi asuransi jiwa berjangka pada kasus umum. Jumlah premi yang harus dibayar sangat ditentukan atau disesuaikan dengan usia peserta asuransi saat mendaftar asuransi dan jangka waktu yang diambil peserta asuransi. Bila usianya semakin tua dan semakin lama jangka waktu yang diambil peserta asuransi, maka premi yang dibayar juga semakin besar. Jika tingkat bunga naik, maka premi yang dibayar kemungkinan akan turun, tetapi besar uang pertanggungan yang diterima jika tertanggung meninggal dunia jumlahnya tidak berubah sesuai dengan nilai pertanggungan yang ditentukan 9 .

Selanjutnya pemodelan intensitas transisi dan peluang pada asuransi perawatan jangka panjang, dengan hasil yaitu proses atau perubahan status kesehatan seseorang pada asuransi perawatan jangka panjang dengan tiga keadaan (sehat, perawatan jangka panjang, dan meninggal) dapat dimodelkan dengan model multi status ${ }^{10}$. Dasar dari model multi status

6 Irwan and Didi Haryono, Pengendalian Kualitas Statistik (Pendekatan Teoritis Dan Aplikatif) (Bandung: Alfabeta, 2015).

7 Rudi Ruswandi, "Menentukan Nilai Premi Tunggal Aktuaria (Actuarial Present Value) Pada Kasus Multi-State Untuk Data CCRC," Jurnal Sains MIPA Universitas Lampung 3, no. 3 (March 3, 2012), http://jurnal.fmipa.unila.ac.id/sains/article/view/105.

8 Sitti and dkk, "Premi Untuk Asuransi Jiwa Berjangka Pada Kasus Multistate."

9 Suyanti, "Menentukan Premi Tunggal Dan Risiko Pada Kasus Multistate Menggunakan Rantai Markov Waktu Kontinu Homogen” (Skripsi, Lampung, Jurusan Matematika FMIPA Universitas Lampung, 2015).

10 Rosita Kusumawati and Gunardi Gunardi, "Pemodelan Intensitas Transisi Dan Peluang Pada Asuransi Perawatan Jangka Panjang," BIMIPA 23, no. 1 (January 29, 2014): 95101. 
adalah rantai markov waktu kontinu dengan banyak status hingga yang direpresentasikan ke dalam model peluang transisi dari suatu keadaan ke keadaan lain. Model peluang transisi yang didapatkan merupakan suatu sistem persamaan diferensial linear orde satu yang beberapa direduksi menjadi orde dua homogen. Solusi analitiknya dapat menggunakan metode separasi, metode faktor integral dan metode persamaan karakterisktik.

Selanjutnya, penghitungan premi asuransi long term care untuk model multi status dengan berbagai asumsi yang berbeda-beda1112, penentuan cadangan asuransi jiwa multilife dengan asumsi pada model semi markov ${ }^{13}$, dan premi asuransi perawatan jangka panjang14. Kajian tentang perhitungan asuransi tersebut akan terus berkembang yang didasarkan pada jenis variabel yang diteliti dengan berbagai asumsi yang lebih variatif. Tentunya, kajian atau penelitian tersebut memberikan dampak pada perkembangan asuransi yang lebih baik. Adapun fokus kajian dalam penelitian ini yaitu penerapan metode Markov Chain dalam menghitung premi asuransi pada penderita penyakit demam berdarah dengue (DBD) di Rumah Sakit Labuang Baji.

\section{Metode}

Jenis penelitian dalam paper ini yaitu penelitian terapan atau applied research dengan jenis data sekunder yang diperoleh dan bersumber di Rumah Sakit Labuang Baji Tahun 2014-2015. Adapun prosedur penelitian yaitu meliputi:

1. Untuk mengetahui pemodelan asuransi jiwa yang dimodelkan yaitu sebagai berikut:

a. Menghitung state awal

b. Menghitung perpindahan state yang diperoleh dari data rekam medis.

11 Chrysmandini Pulung Gumauti, Yuciana Wilandari, and Rita Rahmawati, “Penghitungan Premi Asuransi Long Term Care Untuk Model Multi Status," Jurnal Gaussian 5, no. 2 (April 29, 2016): 259-67.

12 Syamdena Lolanda, "Actuarial Present Value Pada Asuransi Long Term Care Dengan Kasus Multistates” (masters, Universitas Andalas, 2019), http://scholar.unand.ac.id/47675/.

13 I. Gusti Nyoman Yudi Hartawan, "Penentuan Cadangan Asuransi Jiwa Multilife Dengan Asumsi Semi Markov," Wahana Matematika dan Sains: Jurnal Matematika, Sains, dan Pembelajarannya 8, no. 1 (August 26, 2017): 77-87, https://doi.org/10.23887/wms.v8i1.11854.

14 Tasnim Rahmat, "Premi Asuransi Perawatan Jangka Panjang," EKONOMIKA SYARIAH: Journal of Economic Studies 1, no. 2 (February 7, 2018), https://doi.org/10.30983/es.v1i2.426. 


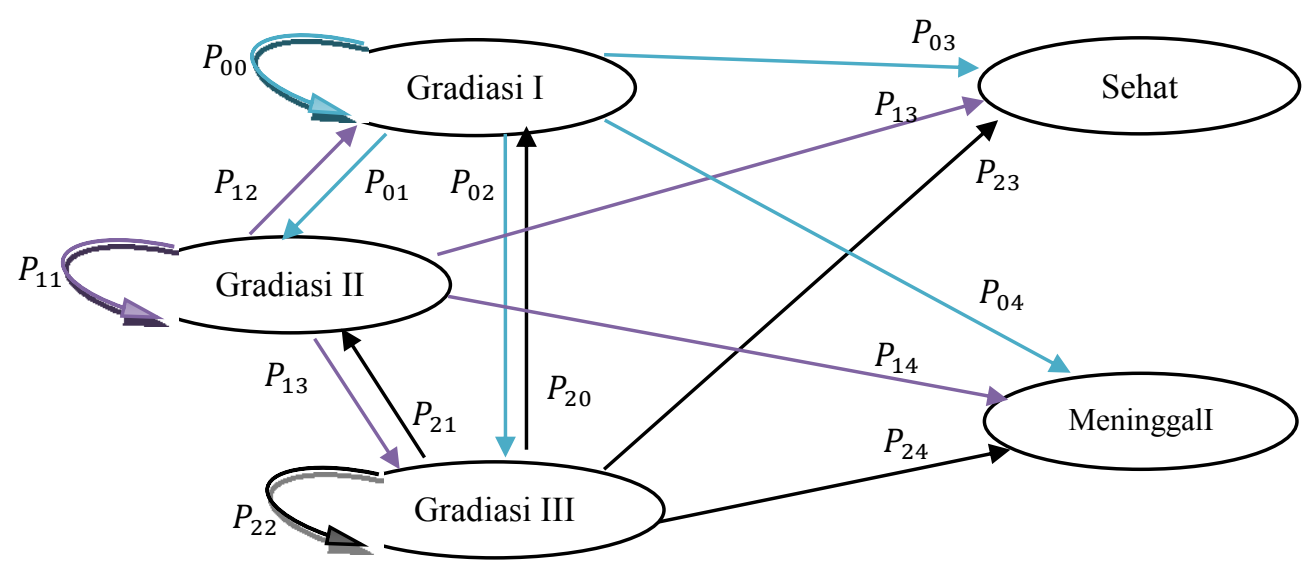

Gambar 1. Perpindahan State

c. Menghitung probabilitas transisi $\left(P_{i j}\right)$, yaitu dengan perhitungan klasik dan peluang bersyarat. Dengan persamaan.

$$
\boldsymbol{P}(\boldsymbol{t})=\left[\begin{array}{ccccc}
P_{00}(t) & P_{01}(t) & P_{02}(t) & P_{03}(t) & P_{04}(t) \\
P_{10}(t) & P_{11}(t) & P_{12}(t) & P_{13}(t) & P_{14}(t) \\
P_{20}(t) & P_{21}(t) & P_{22}(t) & P_{23}(t) & P_{24}(t) \\
P_{30}(t) & P_{31}(t) & P_{23}(t) & P_{33}(t) & P_{34}(t) \\
P_{40}(t) & P_{41}(t) & P_{24}(t) & P_{43}(t) & P_{44}(t)
\end{array}\right]
$$

d. Dari matriks probabilitas transisi maka diperoleh model yang akan digunakan.

2. Untuk mengetahui perhitungan premi asuransi menggunakan metode markov dengan menggunakan model matriks probabilitas transisi, maka:

a. Menghitung entrain matriks laju transisi untuk setiap nilai $\mu_{i j}(t)$ yaitu

$$
\boldsymbol{M}=\left[\begin{array}{ccccc}
-\mu_{00} & \mu_{01} & \mu_{02} & \mu_{03} & \mu_{04} \\
\mu_{10} & -\mu_{11} & \mu_{12} & \mu_{13} & \mu_{14} \\
\mu_{20} & \mu_{21} & -\mu_{22} & \mu_{23} & \mu_{24} \\
\mu_{30} & \mu_{31} & \mu_{32} & -\mu_{33} & \mu_{45} \\
\mu_{40} & \mu_{41} & \mu_{42} & \mu_{43} & -\mu_{44}
\end{array}\right]
$$

Dengan, $\mu_{i j}(t)=\lim _{t \rightarrow u} \frac{P_{i j}(t, u)-\delta_{i j}}{u-t}$, dimana Dengan $\delta_{i j}$ disebut dengan kronecker delta yaitu :

$$
\delta_{i j}= \begin{cases}1, & i=j \\ 0, & i \neq j\end{cases}
$$

b. Dengan memanfaatkan matriks laju transisi, menentukan fungsi peluang transisi dengan Matriks Infinitesimal Generator (matriks pembangun), yaitu mencari matriks diagonal (D), matriks vektor eigen (A), dan invers dari matriks A (C) dengan persamaan sebagai berikut:

$$
\boldsymbol{P}_{i j}(t)=\sum_{k=0}^{4} a_{i k} c_{k j} e^{d_{k} t}
$$


c. Menentukan fungsi densitas dari variabel random $T(x)$ yaitu:

$$
f_{T(x)}(t)=\boldsymbol{P}_{i j}(t) \mu_{i j}
$$

d. Menghitung premi bersih dengan persamaanya yaitu:

$$
{\overline{A^{\prime}}}_{x: \bar{n} \mid}=\sum_{k=0}^{4} \frac{1}{\left(\delta-d_{k}\right)}\left(1-e^{-\left(\delta-d_{k}\right) n}\right) a_{i k} c_{k j} \mu_{i j}
$$

\section{Hasil dan Diskusi}

\section{a) Menentukan Probabilitas Setiap Kejadian}

Probabilitas kejadian dalam penenlitian ini mengikuti proses Bernouli yang terdiri dari dua kejadian yaitu kejadian sukses artinya berpindah status, dan kejadian gagal artinya tidak berpindah status yang lain.

Probabilitas sukses disimbolkan dengan $p$ dan probabilitas gagal disimbolkan dengan $q$ atau $1-p$.

Membuat matriks probabilitas transisi dengan rumus metode klasik dan peluang bersyarat ${ }^{1516}$,.maka matriks probabilitas transisinya adalah sebagai berikut:

$$
\boldsymbol{P}(\boldsymbol{t})=\left[\begin{array}{ccccc}
0.0769 & 0.5000 & 0.6071 & 0.5875 & 0.2222 \\
0.2375 & 0.0385 & 0.2143 & 0.2500 & 0.2222 \\
0.2000 & 0.1579 & 0.0288 & 0.1625 & 0.5556 \\
0.0000 & 0.0000 & 0.0000 & 0.0000 & 0.0000 \\
0.0000 & 0.0000 & 0.0000 & 0.0000 & 0.0000
\end{array}\right]
$$

Berdasarkan hasil perhitungan probabilitas transisi yang diperoleh, dimana hasil matriks probabilitas transisi $\left(P_{i j}(t)\right)$ berdasarkan Persamaan (1), yang merupakan entrain dari matriks laju transisi $\mathbf{M}$, maka untuk entrain matriks laju transisinya berrdasarkan Persamaan (2) adalah sebagai berikut:

$$
\mathbf{M}=\left[\begin{array}{ccccc}
-0.9231 & 0.5000 & 0.6071 & 0.5875 & 0.2222 \\
0.2375 & -0.9615 & 0.2143 & 0.2500 & 0.2222 \\
0.2000 & 0.1579 & -0.9712 & 0.1625 & 0.5556 \\
0.0000 & 0.0000 & 0.0000 & -1.0000 & 0.0000 \\
0.0000 & 0.0000 & 0.0000 & 0.0000 & -1.0000
\end{array}\right]
$$

Kemudian untuk hasil perhitungan peluang transisi berdasarkan Persamaan (3) dan fungsi densitas berdasarkan Persamaan (4) untuk setiap kejadian dapat dilihat pada Tabel 1.

15 Harinaldi, Prinsip-Prinsip Statistik Untuk Teknik Dan Sains (Penerbit Erlangga, 2005).

16 Irwan and Haryono, Pengendalian Kualitas Statistik (Pendekatan Teoritis Dan Aplikatif). 
Tabel 1. Nilai Peluang Transisi dan Fungsi Densitas

\begin{tabular}{ccc}
\hline No & Peluang Transisi $\left(\boldsymbol{P}_{\boldsymbol{i j}}\right)$ & Fungsi densitas $\left(\boldsymbol{f}_{\boldsymbol{T}(\boldsymbol{x})}\right)$ \\
\hline 1 & 0.4484 & -0.4139 \\
\hline 2 & 0.2232 & 0.1116 \\
\hline 3 & 0.2680 & 0.1627 \\
\hline 4 & 0.2807 & 0.1649 \\
\hline 5 & 0.9174 & 0.2038 \\
\hline 6 & 0.1055 & 0.0251 \\
\hline 7 & 0.4153 & -0.3993 \\
\hline 8 & 0.1140 & 0.0244 \\
\hline 9 & 0.1335 & 0.0334 \\
\hline 10 & 0.1247 & 0.0277 \\
\hline 11 & 0.0888 & 0.0178 \\
\hline 12 & 0.0828 & 0.0131 \\
\hline 13 & 0.4120 & -0.4001 \\
\hline 15 & 0.0960 & 0.0156 \\
\hline
\end{tabular}

\section{b) Menghitung Premi}

Dengan memperoleh nilai fungsi densitas pada Tabel 4, maka berdasarkan Persamaan (5), besar premi asuransi jiwa berjangka yang dibayarkan secara periodik yaitu 1 tahun, yang berlaku untuk pasien Demam Berdarah Dengue (DBD). Jika untuk setiap pasien Demam Berdarah Dengue (DBD) diperoleh nilai ${\overline{A^{\prime}}}_{x: \bar{n} \mid}$, dimana ${\overline{A^{\prime}}}_{x: \bar{n} \mid}$ merupakan pembobot santunan untuk satu satuan mata uang serta nilai akumulasi dari semua premi tahunan yang dibayar sepanjang kontrak. Dimisalkan (B) santunan sebesar Rp. $500.000 \times{\overline{A^{\prime}}}_{x: \bar{n} \mid}$ sama dengan besar premi yang di bayar sepanjang kontrak.

Sehingga untuk setiap keadaan besar premi yang di bayarkan adalah sebagai berikut :

1. Keadaan Gradiasi I

Pada keadaan tetap gradiasi I dengan nilai ${\overline{A^{\prime}}}_{x: \overline{1} \mid 00}=1.5966 x \mathrm{Rp}$. 500.000, maka besar premi yang di bayarkan adalah Rp. 796.350, Sedangkan untuk keadaan gradiasi I berpindah ke keadaan gradiasi II dengan nilai $\bar{A}_{x: 1 \mid 01}^{\prime}=2.6867 \times$ Rp. 500.000, maka besar premi yang di bayarkan adalah Rp. 1.343.350, keadaan gradiasi I berpindah ke gradiasi III dengan nilai ${\overline{A^{\prime}}}_{x: \overline{1} \mid 02}=2.7190 x$ Rp. 500.000, maka besar premi yang di bayarkan adalah Rp. 1.359.500, keadaan gradiasi I berpindah ke sehat dengan nilai ${\overline{A^{\prime}}}_{x: \overline{1} \mid 03}=2.7204 x$ Rp. 500.000, maka besar premi yang di bayarkan adalah Rp. 1.360.200 dan keadaan gradiasi I berpindah ke meninggal dengan nilai 
${\overline{A^{\prime}}}_{x: \overline{1} \mid 04}=2.7450 x$ Rp. 500.000, maka besar premi yang di bayarkan adalah Rp. 1.372 .500 .

2. Keadaan Gradiasi II

Pada keadaan gradiasi II berpindah ke gradiasi I dengan nilai ${\overline{A^{\prime}}}_{x: \overline{1} \mid 10}=2.6320 x$ Rp. 500.000, maka besar premi yang di bayarkan adalah Rp. 1.316.000 sedangkan untuk keadaan tetap gradiasi II dengan nilai ${\overline{A^{\prime}}}_{x: \overline{1} \mid 11}=1.6029 x$ Rp. 500.000, maka besar premi yang di bayarkan adalah Rp. 801.450, keadaan gradiasi II berpindah ke gradiasi III dengan nilai ${\overline{A^{\prime}}}_{x: \overline{1} \mid 12}=2.6316 x$ Rp. 500.000, maka besar premi yang di bayarkan adalah Rp. 1.1315.800, keadaan gradiasi II berpindah ke sehat dengan nilai ${\overline{A^{\prime}}}_{x: \overline{1} \mid 13}=2.6373 x$ Rp. 500.000, maka besar premi yang di bayarkan adalah Rp. 1.318.650 dan keadaan gradiasi II ke meninggal dengan nilai ${\overline{A^{\prime}}}_{x: \overline{1} \mid 14}=2.6337 x$ Rp. 500.000, maka besar premi yang di bayarkan adalah Rp. 1.316 .850 .

3. Keadaan Gradiasi III

Pada keadaan gradiasi III berpindah ke keadaan gradiasi I dengan nilai ${\overline{A^{\prime}}}_{x: \overline{1} \mid 20}=2.6274 x$ Rp. 500.000, maka besar premi yang di bayarkan adalah Rp.1.313.700, sedangkan untuk keadaan gradiasi III berpindah ke gradiasi II dengan nilai ${\overline{A^{\prime}}}_{x: \overline{1} \mid 21}=2.6245 x$ Rp. 500.000, maka besar premi yang di bayarkan adalah Rp. 1312.250, keadaan tetap pada gradiasi III dengan nilai ${\overline{A^{\prime}}}_{x: \overline{1} \mid 22}=1.6025 x$ Rp. 500.000, maka besar premi yang di bayarkan adalah Rp 801250, keadaan gradiasi III berpindah ke sehat dengan nilai ${\overline{A^{\prime}}}_{x: \overline{1} \mid 23}=2.6260 x$ Rp. 500.000, maka besar premi yang di bayarkan adalah Rp. 1.313.000 dan keadaan gradiasi III berpindah ke meninggal dengan nilai ${\overline{A^{\prime}}}_{x: \overline{1} \mid 24}=2.5701 x$ Rp. 500.000, maka besar premi yang di bayarkan adalah Rp. 1.285.050.

\section{Kesimpulan}

Model matriks probabilitas transisi yang didapatkan dengan kasus multistate yaitu dengan matriks yang berukuran $5 x 5$ yaitu:

$$
\boldsymbol{P}(\boldsymbol{t})=\left[\begin{array}{ccccc}
0.0769 & 0.1154 & 0.1154 & 0.4519 & 0.0192 \\
0.0673 & 0.0385 & 0.0481 & 0.2019 & 0.0192 \\
0.0481 & 0.0096 & 0.0385 & 0.1346 & 0.0481 \\
0.0000 & 0.00000 & 0.0000 & 0.0000 & 0.0000 \\
0.0000 & 0.0000 & 0.0000 & 0.0000 & 0.0000
\end{array}\right]
$$


Sedangkan besar premi asuransi jiwa berjangka 1 tahun yang dibayarkan untuk setiap pasien Demam Berdarah Dengue (DBD) bedasarkan pembobot $\left({\overline{A^{\prime}}}_{x: \bar{n} \mid}\right)$ dengan santunan (B) sebesar Rp. 500.000 dengan besar premi yang di bayarkan disesuaikan dengan keadaan masing-masing gradiasi I, II, dan III, dengan nilai maksimal premi yang di bayarkan yaitu pada keadaan gradiasi I yang berpindah ke meninggal dengan nilai $\bar{A}_{x: \overline{1} \mid 04}=R p .1 .372 .500$. Adapun saran untuk pengembangan penelitian selanjutnya yaitu dengan melibatkan data multitahun dari beberapa rumah sakit yang berbeda.

\section{Daftar Pustaka}

Anna Islamiyati. "Estimator Penalized Spline Pada Model Regresi Nonparametrik Multirespon Multiprediktor Untuk Data Longitudinal." Postdoctoral, Universitas Airlangga, 2019. http://lib.unair.ac.id.

Baione, Fabio, and Susanna Levantesi. "A Health Insurance Pricing Model Based on Prevalence Rates: Application to Critical Illness Insurance." Insurance: Mathematics and Economics 58, no. C (2014): 174-84.

Faihatuz, Zuhairo. Diklat Kuliah Matematika Asuransi. Makassar: FST UIN Alauddin, 2012.

Gumauti, Chrysmandini Pulung, Yuciana Wilandari, and Rita Rahmawati. "Penghitungan Premi Asuransi Long Term Care Untuk Model Multi Status." Jurnal Gaussian 5, no. 2 (April 29, 2016): 259-67.

Harinaldi. Prinsip-Prinsip Statistik Untuk Teknik Dan Sains. Penerbit Erlangga, 2005.

Hartawan, I. Gusti Nyoman Yudi. "Penentuan Cadangan Asuransi Jiwa Multilife Dengan Asumsi Semi Markov." Wahana Matematika dan Sains: Jurnal Matematika, Sains, dan Pembelajarannya 8, no. 1 (August 26, 2017): 77-87. https://doi.org/10.23887/wms.v8i1.11854.

Irwan, and Didi Haryono. Pengendalian Kualitas Statistik (Pendekatan Teoritis Dan Aplikatif). Bandung: Alfabeta, 2015.

Kusumawati, Rosita, and Gunardi Gunardi. "Pemodelan Intensitas Transisi Dan Peluang Pada Asuransi Perawatan Jangka Panjang." BIMIPA 23, no. 1 (January 29, 2014): 95-101.

Lolanda, Syamdena. "Actuarial Present Value Pada Asuransi Long Term Care Dengan Kasus Multistates." Masters, Universitas Andalas, 2019. http://scholar.unand.ac.id/47675/.

Rahmat, Tasnim. "Premi Asuransi Perawatan Jangka Panjang." EKONOMIKA SYARIAH: Journal of Economic Studies 1, no. 2 (February 7, 2018). https://doi.org/10.30983/es.v1i2.426.

Ruswandi, Rudi. "Menentukan Nilai Premi Tunggal Aktuaria (Actuarial Present Value) Pada Kasus Multi-State Untuk Data CCRC.” Jurnal Sains MIPA Universitas Lampung 3, no. 3 (March 3, 2012). http://jurnal.fmipa.unila.ac.id/sains/article/view/105.

Sitti, Aminah, and dkk. "Premi Untuk Asuransi Jiwa Berjangka Pada Kasus Multistate.” Skripsi, Universitas Riau, 2015. 
160 Irwan, dkk/Al-Khwarizmi: Jurnal Pendidikan Matematika dan Ilmu Pengetahuan Alam, Oktober-2019, Vol.7, No.2, hal.151-160

Suyanti. "Menentukan Premi Tunggal Dan Risiko Pada Kasus Multistate Menggunakan Rantai Markov Waktu Kontinu Homogen." Skripsi, Jurusan Matematika FMIPA Universitas Lampung, 2015.

Utami, Rianti Siswi, and Adhitya Ronnie Effendie. "Model Hidden Markov Multistatus Untuk Menghitung Premi Asuransi Kesehatan," 2014. http://etd.repository.ugm.ac.id/home/detail_pencarian/69145. 